\title{
Manifestations of Place in Al-Raneen Short Story Collection by Amin Oudah: an Analytical Study
}

\author{
Mohammad Issa Alhourani', Suad Al-Waely ${ }^{2}$ \& Tar Abdallahi ${ }^{3}$ \\ ${ }^{1,2,3}$ College of Education, Humanities, and Social Sciences, Al Ain University \\ Emails:mohammad.al-hourani@aau.ac.ae,suad.alwaely@aau.ac.ae, \\ tar.abdallahi@aau.ac.ae
}

\begin{abstract}
This research paper aims at examining the experience of Amin Oudah in his second short story collection, Al-Raneen. In addition to introducing the writer and highlighting his literary contributions, the paper introduces the reader to the short story collection entitled Al-Raneen. It briefly introduces each story and provides a quick comment on it, with the aim of coming up with a overall perception of all the stories in the collection. In addition, we dedicate a section of the paper to the study of Hamdan's Shoes, one of the short stories in the collection. This case study provides insights into this particular story and highlights the most significant features that all the stories have in common.
\end{abstract}

Key words: Al-Raneen, Ringing, Amin Oudah, short story, place

\section{Introduction}

This research paper aims at examining the experience of short story writer, Amin Oudah in his second short story collection, Al-Raneen, which was published in 1991. This short story collection, in our view, is an extension of his previous collection entitled: Transformations of Mustapha Jabir. Although the writer occupies a significant place in the history of short story in Jordan and Palestine, and was considered part of the 1990s' generation of fiction writers, he had not written a new collection since then. This was perhaps due to his academic engagements.

Regardless of the reasons, the focus of this paper is studying the short story collection (AlRaneen), whose stories represent altogether a high level of creativity. This was picked up by critics and readers at the time of its publication. For instance, it was the subject of several studies. Some of them examined the collection as a whole, while others focused on specific stories.

One of the primary challenges that faced this study was the difficulty to have access to the critical studies dispersed in local newspapers at the time. Another one was the paucity of research studies that rely on an easy-to-refer-to reference book. Such studies are analysis-centred, and they are based on the structure of the story which largely revolves around the place and feeling it. Critics' refer to this as aesthetics. It means "the science concerned with sensory knowledge. It is a type of perception that is different from the pure intellective way of thinking.",

This study is divided into three sections, in addition to the introduction and conclusion. The first section introduces the writer and his short story collections. It briefly reviews his

(C) AesthetixMS 2020. This Open Access article is published under a Creative Commons Attribution Non-Commercial 4.o International License (http://creativecommons.org/licenses/by-nc/4.o/), which permits non-commercial re-use, distribution, and reproduction in any medium, provided the original work is properly cited. For citation use the DOI. 
biography and contribution to the academia and fiction writing. It also looks into his two short story collections. The second section deals with the short stories in the collection entitled: ALRaneen or Ringing. It briefly introduces each story and provides a quick comment on it, with the aim of coming up with an overall perception of all the stories in the collection

The final section is a case study on Hamdan's Shoes, as representative of the rest of the stories in the collection. This section also highlights the most significant features that these stories have in common. The study concludes with reviewing the primary findings and then it lists references.

\section{Section I}

\section{Author Biography}

Amin Yousuf Oudah was born in 1958, in Aqabat Jabr refugee camp, Jericho. He moved to Amman with his family amid the naksa (Israel's victory) in 1967. There, he completed high school and then he studied medical laboratory science and got a diploma in this field. After that, he received a BA, MA, and PhD respectively in Arabic literature. Currently, he works as a professor in the Arabic Department at $\mathrm{Al}$ al-Bayt University in Jordan. He is a member of the Jordanian Association of Writers, the Arab Writers Union, and Jordanian Critics Association. He participated in a number of local and international conferences and symposiums on literature and literary criticism.

He has won several awards such as the Writers Association Award, the Cultural Constitution Award, Al Yarmuk University Award, the Award of the Arabic Word Center for Publishing and distribution in Alexandria, and Dr. Souad Sabah Award for Arabic Intellectual Creativity, 1988. He published several research papers and studies in local, Arabic and international journals. He wrote the following two short story collections:

> Tahawulat Mustapha Jabir (تحو لات مصطفى جابر) Irbid: Qudsiyah for Publishing and Distribution, 1990

> Al-Raneen (الرنين) Irbid: Qudsiyah for Publishing and Distribution, 1991

In Literary criticism, he published the following works:

Sufis' Interpretation of Poetry and Philosophy (ibn Arabi), (تأويل الثعر و الفلسفة عند الصوفية (ابن عربي)) Jordanian Writers Association, Amman: 1995

Manifestations of Sufi poetry, A look into Spiritual States (ahwal) and Stage (maqamat) ( تجليات (الثعر الصوفي، قر اءة في الأحوال و المقامات

\section{Short story collections}

Amin Oudah wrote two short story collections. The first one was published by Qudsiyah for Publishing and Distribution in Irbid, in 1990, under the title: Transformations of Mustapha Jaber. The total number of pages is 104 pages, small size. It included six short stories, the size of which ranges from seven to thirty pages.

This collection tackles issues of concern to the Arabic intellectual and the Palestinian citizen. It deals with the atmosphere prevailing after the defeat of Arabs in the face of the Zionist tide. This defeat resulted in waves of displacement and immigration to refugee camps inside and 
outside of Palestine, marking a new phase of alienation. "Alienation varies depending on where the person is. At the refugee camp, poverty is manifested in various forms, and challenge crystallizes in absurd ways. However, the most painful scenes are those of dispersion, separation, and waiting." "iii

The themes of this short story collection were largely inspired by Palestinian youth planted in the refugee camps, namely the educated, resistant, arrested, and unemployed youth. It is about all what these youth became; this human being who was uprooted from his home and became homeless in places that leave psychological and social impact in him.

The second collection was published in 1991 by the same company that published the first one. In small sized eighty-eight pages, the collection encompasses seven stories the length of which ranges between four and seventeen pages. This short story collection is the subject of this paper.

\section{Section II: A Brief Overview of the Stories in al-Raneen Collection}

\section{Hamdan's Shoes}

The setting is a tinplate room in the refugee camp. Hamdan returns from school, excited about the arrival of Eid; his mother had promised to buy him a pair of shoes (kandara) on this occasion. The pair of shoes he is wearing does not in any way resemble shoes. The mother is too busy taking care of his sick sister and providing the family basics, despite the pressure of financial burdens. Therefore, she does not care about his request. Angrily, he leaves the house in a miserable and rebellious way, throwing stones. Darkness befalls, but Hamdan never returns home. The mother, occupied with her daily routine tasks, lights the portable gas burner to provide heating for her sick daughter. The sound of the portable gas burner intersects with that of the rain thrumming on the roof of the room. Meanwhile, Hamdan is outside stumbling onto the ponds in the camp alleys. The next morning, the camp wakes up to the miserable ending of the boy and his pair of shoes.

This story reflects "a level of early consciousness on the part of the camp child. Hamdan refuses to wear the ripped shoes, erupts in his mother's face, and throws rocks at the house. It is an internal desire to revolt against the place, for the place is just a camp and it should be temporary. iv",

The main character here reminds us of the main character in The Story of a Pair of Shoes who was defeated while facing the backward forces, but Hamdan, with consciousness and persistence, attempts to fight his war alone, a war against the new, harsh reality. The construction of the story is classical and simple. The events develop smoothly and grow naturally. As the title indicates, the topic of the story is derived from ordinary people's reality.

\section{The Case of a Chronic Insomnia}

Based on the reality, the story depicts a person who suffers from a chronic insomnia to the extent that it becomes a normal thing in his life. The story, however, takes a symbolic, nightmarish turn. The character passes by an open spring. Inside the water, he sees terrifying scenes: human body parts and a corpse of a child who was still alive. The narrator had paved the way for this turn when he said that he noticed a small crack in the street asphalt the previous week. At that moment, a fracture disturbed the monotony of the days. Something strange fell in a strange place 
at a strange moment and fell into it. Seeing what was inside the crack, or the sewage stream, provoked his anguish, which is already caused by his chronic insomnia ${ }^{\mathrm{v}}$.

Taking the story to this nightmarish level resonates with what we see in reality. Perhaps what we hear about is even beyond imagination. Creativity, however, brings a special touch to reality. The writer revisits reality through the story in a new way. As he said in an interview, "in fact, this cannot be achieved apart from imagination, for the latter has a powerful force through which we can create what the mind and reality fail to create. Thus, The Story of a Shoe was full of the inconceivable, and so was The Case of a Chronic Insomnia. It allows me to say the things I can't say the conventional way ${ }^{\mathrm{vi}}$.

\section{Al-Raneen (Ringing)}

This short story also has a nightmarish dimension. The narrator divides it into two sections. In the first section, the main character, Qamar al-Zaman, aspires to win one of the three roses thrown at people by the sultan. This is very ambitious because winning one of these roses leads to eternal happiness. The sultan usually throws roses once a decade. Qamar al-Zaman misses the opportunity because he falls asleep. When the third chance arrives, he leaves quickly, blending in with the large crowds. He sees the sultan's glorious face. However, the narrator does not tell us whether Qamar al-Zaman ended up picking one of the roses or not.

In the other section, the character of Qamar al-Zaman is manifested in a man who reads newspapers. He often sits in a modern café. He is employed and has a fiancée but his problem lies in premonitions related to what he reads. Wherever he looks, he reads death, killing, and blood. This vocabulary represents a nightmare that blows up after he wakes up to the alarm which refuses to go off. It keeps ringing, creating an unprecedented case of breakdown. Despite all attempts, which ended in throwing the alarm away from the window, the ringing continued to storm his mind. The story ended with the ringing still continuing.

In this story, the writer combines heritage dimensions with surreal realism. The story relies on the confrontation between two voices; the voice of Qamar al-Zaman, which was formed in the past as a shadow of the sultan, and the voice of the modern Qamar al-Zaman who is steeped in the anxiety of spurious modernization. The ringing starts again coming from deep inside and prevails over everything ${ }^{\text {vii }}$.

\section{The Stone}

This story revolves around an elegant young man who stumbles on a stone and falls in the mud. He attempts to take out a napkin from his pocket without getting his coat pocket dirty. He keeps trying but he fails. His pocket gets dirty and he still cannot find the napkin. The mud reaches his shirt and pants, so he resorts to cursing to release his anger and contempt. Meanwhile, a young man passes by, scanning the shops' doors with eyes. 'If I were you, I wouldn't look behind while walking', the young man says. His rage escalates. He looks behind to see two men whispering and looking at him. He takes a stone and throws it in their direction. This leads to the beginning of a battle that starts with a stone and ends with people going crazy in the alleys and streets, throwing each other with whatever objects they lay their eyes on.

This story reflects the personality of the narrator. "It appears to be a typical character; the likes of which live among us. It is a peripheral personality, caught up with angry emotions, cursing, and too much interest in appearance. Our character is occupied with trivial aspects of life. He is always looking down, either fantasizing a sensual women-related scene or avoiding the 
eyes of others. viii" This faltering character is, perhaps, a symbolic expression of the Arabic person who is too busy to care about the Cause, the one that witnessed the birth of the stone revolution.

\section{Two Short Stories}

\section{-1- The Cat and the Mouse}

The story starts with the description of a skinny cat searching inside the garbage for something to eat. A fat, black mouse comes out and begins talking to the cat and mocking it. After engaging in a dialogue, the mouse agrees to give the cat a piece of cheese provided that it is allowed to ride on the back of the cat. The writer gives a modern human dimension to this story, a dimension in which the situation is reversed and tables are turned.

\section{-2- They Were Four}

An extension of the previous one, this story starts with four people sitting around a table. Each one of them recounts a dream he saw. The first one dreamed that he was wearing rugs while the city was naked. Everything was naked. Trees were naked. People were naked. The city was made of nakedness. The flood was naked. People were running after him. When he went out, they closed the naked gate of the city.

The second one dreamed that he was walking in a cemetery. He dug a grave and slept inside it. When he slept, he dreamed again about an open grave. He covered it over with dust and watered it, and then a green head sprouted through it.

The third one dreamed that he was a puppet. Finally, the fourth one dreamed about an elegant man carrying a gold inlaid stick and bowing to a naked chicken.

What these dreams have in common is the universal nakedness, reflected in the nakedness of the city, the people, and life itself. The first and the second represent human being's need for what conceals their nakedness. It is the grave that covers the naked corpse. The third and fourth dreams are related to the vanishing material life. This is represented in the bowing to the naked chicken.

When we come to the point where the mouse is threatened by the cat and the cat begs the mouse which accepts to help the cat under the condition of allowing him to ride on his back, when things get to this stage, this means that our life has turned upside down and gone incongruent to the normal way ${ }^{\mathrm{ix}}$. That is why these four dreams were resorted to. They are, however, dreams that illustrate the bizarre life we lead.

\section{Amman's Days (1)}

The place represents one of the most important elements of this story. It accompanies the main character as he escapes the hot weather and Amman's traffic jam and resorts to the shade of the Hussaini Mosque, one of Amman's most notable historic sites. As the character seeks shade under the Mosque's wall, he invokes a myriad of observations: the pedestrians' footsteps, the cars, and the noise. All these pieces make up the framework encircling the image of Amman's days. The nights, however, are completely different.

"When it is an imagined esthetic subject, the place acquires the property of creative impact, in which the reader has complete authority over meaning-making ${ }^{\mathrm{x}}$.

As the character takes a rest, his ears pick the sound of the Muqri' reciting the Quran and the gentle sound of water flowing from a nearby fountain. The narrator recalls the childhood days 
in Ramadan, when he used to resort to the Mosque in the afternoon and see the fountain which stimulated his feeling of thirst, an overwhelming feeling that could only be interrupted by the sound of the young mu'azin and the scent of perfume coming from a nearby perfumery.

After stepping out of the Mosque, he accurately portrays the female beggars. Then, he describes how he and his father arrives to the Mosque to perform the Eid prayer. He describes the Mosque podium (minbar), the dome, and the inscriptions. After leaving the Mosque, he also describes the Eid atmosphere in the streets, markets, and alleys, and the visits by relatives and sisters. The visits continue during that day, and the writer takes us to a new place, al-Wehdat Refugee Camp, to visit the grandmother and the uncle. Here, we discover through several dialogues, that the son is the only child of his parents and that his father used to over-indulge him and love him. He used to take him to the places he visited, and he used to be very much concerned about of him. However, as it is shown at the end of the story, the father had gone and left his child to loss and alienation. The father is the support, but the support has gone. The story ends as it started. It started with the son asking: 'O' father, how...?" And it ends with him asking: 'O' father, how could you leave me without a support!"

\section{Amman's Days (2)}

The domination of the place continues. It is the same place: Amman and its busy days and tall buildings. The son becomes older. The same question arises again: Why did I grow up? Then, he turns to the question in the first section: Father, why did you leave me without a support in the midst of this crowd!

In the first section, he is with the father in his childhood. The soul and the body are filled with spiritual dimensions near the Hussaini Mosque. The second section, however, portrays his life after losing the father and growing up with a lack of support. The setting is now the café, and the son turns to smoking. He regularly sits in the café and listens to Turkish songs. He describes Turkish music in details. There is an extended dialogue between him and the café owner who inherited the café from his Turkish wife. Although the son (Salim) is educated, as he is a philosophy graduate, he has no money, and he still cannot find a job. Meanwhile, Azmi has money as he became a business owner. Here, we are introduced to the place in which Salim finds shelter. It is Al-Hussayn Refugee Camp. Before he returns to the camp, however, he wants to fill his hungry stomach.

It is late, however, and the places are empty. He returns to the camp and describes it to us. He describes the silence, death, and emptiness of everything but insects, coughing, groaning, the darkness enveloping the camp, and the tinplate walls reflecting the nature of the camp. He recalls his fear and his terrifying reflection in the mirror. The fear of getting in the room has become his dilemma, even though no one lives with him. The door opens even before he puts the key in. He sees that person he has always seen in his hallucinations, sitting on a chair. Behind him, the shattered mirror appears. Perhaps, the chair is Salim himself. Perhaps the framework outside is just an echo and a recalling of a past which had already gone.

In both sections of Amman's Days, the writer produced a short story that deserves to be called the story of the place. He managed to give the place a human dimension and deep civilizational roots, making Amman a scene for the human experience, with its psychological, cultural and civilizational dimensions ${ }^{\mathrm{xi}}$. While the first section takes a realistic approach with a familial, social and religious reference, the second section is mixed with the nightmarish dimension appearing from time to time in the rest of the stories of the collection. In the midst of the bitter reality, he goes to the place (the camp) to be confronted by the picture of the monster 
awaiting him. "The real place, however, does not keep all its characteristics when turned into a text $^{\text {xii }}$."

\section{Section III: A Case Study: Hamdan's Shoes}

This short story takes us to spatial reality whose dimensions and minute details are known to us. It is the reality of the refugee camp, the reality of a people exiled from their home country and forcibly taken to refugee camps. At the beginning, they thought these camps were temporary and they are inevitably returning home. Time, however, spread out, and the temporary became eternal, even though it lacks the basics of life. All of this is simplified by the writer in Hamdan's Shoes. Like any other realistic writer, he pays attention to details in order to take us to the heart of the daily life of refugee camp's family.

Hamadan is a small child belonging to a poor family that lives in a tinplate room. Coming from school, he gets home imitating the sound of a car. He throws his school bag, creating a sound as a result of hitting the wall. He dreams of getting a pair of shoes (kandara) to finally get rid of this thing in his foot. His dream falls apart against the pressure of providing life basics on the part of the mother. The mother is busy with her daily routine like any other housewife in the refugee camp: washing clothes by hand, taking care of the sick daughter and making sure she takes her medication, preparing food, sewing, oppression and pain. The supporting husband is completely absent. Although we are overwhelmed by small details, there is no mention of the father and his absence.

The tinplate room is one of the refugee camp's facets. The place is presented as the main character, and the writer focuses on depicting the echoing of all objects that hit the room: the schoolbag, the stone, the door slam, the sound of the portable gas burner, the rain drops as they hit the ground.

In fact, it is a room that is similar to anything but a room. So are Hamdan's shoes. They resemble anything but shoes.

As Hamdan revolts against the place he lives in, the story reveals other places like the camp alleys, mud lakes, chaotic life, and debris of various objects. While the cruelty of life is manifested during the day, the night reflects the struggle against darkness and the unknown aspects of the camp alleys.

It is unusual for the refugee camp child to not come home at night. However, despite the difficulties she faces during the day and attempting to physically punish Hamdan, she is still a mother. Life could not strip her of her maternal instinct. She is, however, forced to be both a mother and a father, managing her household and the life of her family.

The window tarpaulin he teared, as he had thrown a stone in the direction of the house expressing his rebellion, becomes his last means of survival. Even though it can neither replace the shoes nor protect the child's body against the mud and water ponds, it nonetheless represents a significant feature that symbolizes the remains of an innocent life, a child who attempted to venture into a quagmire in one of the camp's dark alleys.

'The writer easily penetrates the inner sides of both the mother and the reader, the same way he goes deeper into Hamdan and the reader at the end of the story. In the picture in which we see the details of the scene as it is uncovered by the morning light; a hurtful picture which is hard to erase. In the beginning of the story or the beginning of the given section, the reader sees 
that worn-out thing in Hamadan's feet. At the end of the story, the reader accompanies Hamdan as he struggles against water and mud to save the same pair of shoes. The dream of getting a new pair of shoes was shattered because his sister is sick and needs medication. ${ }^{\text {xiii", }}$

The writer succeeded in depicting this mixture of spatial environment through a social story with a classical touch. It is characterized by internal consistency or cohesion. Cohesion means that the story, with its events and characters are consistent, compatible, and harmonious. The character speaks in the language that suits him or her. Everything the character portrays is looked at through the lenses of the character and not those of the writer. It focusses on a single moment which indicates the main point ${ }^{\mathrm{xiv}}$. It is the moment of attempting to break away from the dominance of the shanty camp.

\section{General features}

\section{Cultural Values}

Like all other short story collections, the artistic value of these stories varies depending on the story. However, this value does not descend below the average level. Sometimes it even goes up to a level that merits critical reception, and where overlooking it is considered a neglect ${ }^{\mathrm{xv}}$. The stories range between imitating conventional literary works and experimenting new forms. Sometimes they exhibit some aspects of creativity that merit, and at times necessitates, critical attention.

The stories in this collection can, therefore, be divided into two levels. The first one is a simple narration as in the stories of Hamdan's Shoes and Amman's Days. The second one is more in-depth, and it relies on presenting thoughts in a deeper, intellective manner. Examples of this level include the stories of Ringing, The Case of a Chronic Insomnia, and A Stone.

\section{Narration and dialogue}

While narration is the most important element of short story, the "narrative discourse/point of view is the foundation of narration. It is through the narrative discourse that the monologues of the main characters and their dialogues with each other are reflected. Monologue and dialogue are the elements through which we see the world created by the narrator, however intolerable it is; it looks intolerable only from the perspective of reality, which is considered the logical, though not aesthetical, perspective. ${ }^{\text {xvi", }}$

The style of narration in this collection is diverse. Sometimes the writer presents us with a movie scene, as if we are watching the event together with him. Other times, the event is presented through a neutral witness making it more realistic. Often, however, the story is told through a dream or a nightmare transmitted to us through a stream of consciousness which emphasises his inability to face perplexity in multi-event scenes." Also, he often adopts the flashback style whereby the end takes us to the beginning ${ }^{\text {xvii }}$, as in the story of Amman's Days.

\section{Language}

Although the writer adapts his characters to the language they speak, and even though he walks us through the finest details of these characters, the dominance of poetic language - often resulting from the description which the narrator interferes in- is present throughout the dialogues in the stories. Although the story is marked by a realistic framework, the poetic touch affects some sections of the narration. The language in the short stories is characterized by ambiguity, condensation, and metaphor, which are main features of the poetic language ${ }^{\text {xiii }}$. 


\section{References}

The writer's life references in this story are probably the same as his references in the rest of the stories. In general, these stories take the Palestinian diaspora and what these people go through as a reference. In all these stories, we find the refugee camp, the tinplate rooms, the poor services, poverty, sickness, refusal, the UNRWA school, and others...

Thus, the most important reference for these stories is that stage which "reflects false consciousness. We assume that this false consciousness is real and that it will enable us to get rid of what we go through. The main character's discovery of how shallow his knowledge is led to some sort of deterioration. He found out that the path he was taking was wrong. On the other hand, the ringing symbolizes imminent danger which will lead to the complete destruction of all types of change unless the character immediately acts. ${ }^{\text {xix" }}$

It is also noteworthy to refer to the cultural reference, as in the story of Qamar al-Zaman and those key steps which denote a Sufi philosophical dimension. In addition, he dedicated his two collections to Ghassan Kanafani, the symbol of intellectual resistance, and Ahmed Zubi, an old teacher of Oudah and a short story writer.

\section{Stories' Endings}

As a general remark, all these stories share a dramatic ending. This is clear in the tragic ending for Hamdan and his shoes. We were also shocked by the dismembered body parts in the sewage streams and city springs. The ringing sound that prevails over everything gives us a headache. Even in The Stone, we can see how the main character, who is obsessed with his elegance, got stuck in the mud.

\section{Conclusion}

To sum up, Amin Oudah possesses a special touch in the art of short story writing, despite having published only two short story collections. These two collections have a strong influence on the trajectory of short story writing in Jordan and Palestine.

It is notable that his second short story collection is an extension of the first one in terms of performance and references, and that Ringing is overall an expression of a state of chaos and dichotomy of past and present.

It is also worth noticing that this collection is overwhelmed with details which seem to be similar, despite attempts to diversify and include phantasy and reality; the conceivable and inconceivable. Sometimes this diversity exists in a single story, even in those stories with realistic themes.

As we notice, the place is also manifested in these stories; it is even the main focal point in most of them. It is characterized by diaspora and Palestinians' forced displacement.

The three units are clearly reflected in all stories in the collection. Oudah is unquestionably a great writer who possesses artistic techniques and knows how to use them to depict the wounds of the Palestinian people he lived and witnessed. His stories are, therefore, drawn from these sorrows which are reflected in the characters.

Nevertheless, this short story collection remains open for further serious studies. We also hope that the writer embarks on contributing new short stories. 


\section{Endnotes}

i Ismael, Izz Al-din (2001) Al-ussus al-jamaliyah fi-al-naqd al-Arabi (الأسس الجمالية في النقد العربي). Beirut: Dar-alfikr al-Arabi, p.14

معالم الحياة الأدبية في فلسطين (2009). Ma'alim al-hayat al-adabiyah fi Filastin wa-al-Urdun و الأردن: Beirut: Al-mu'assasah al-arabiyah, p.57. See the website of Jordanian Ministry of Culture:

http://www.culture.gov.jo/index.php?option=com_content\&view=article\&id=227\&Itemid=48\&lang=ar

iii Al-Quralah, Zaid (13/11/1992). Al-sira' bayn al-dhat wal-akhar (الصراع بين الذات والآخر) Al-Ra'y Newspaper, AlRa'y al-thaqafi

${ }^{\text {iv }}$ An interview with the writer, al-Ufuq Magazine, first year, 1992, issue 24, p.50

v Al-rimawi, Mahmoud (23/06/1995). Qissass Al-Raneen li Amin Oudah. (قصص الرنين لأمين عودة). Al-Ra'y Newspaper, Cultural Appendix

${ }^{\text {vi }}$ An interview with the writer, al-Ufuq Magazine, 1992, first year, issue 24, p.50

vii Al-Shaykh, Khalil (20/08/1993). Tajribat Amin Oudah wa-al-bahth 'an al-huwiyah al-Qassassiyah ( تجربة) (أمين عودة والبحث عن الهوية القصصية Al-Ra'y Newspaper

viii Haddad, Nabil (2007). Al-ibda' wa-wihdat-al-intiba' (الإبداع ووحدة الانطباع). Amman: Jarir House for Publishing and Distribution, pp.81-82

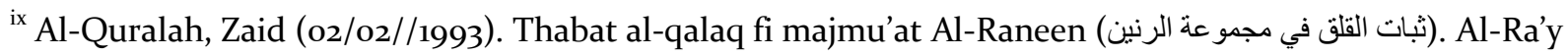
Newspaper

${ }^{x}$ Mu'nissi, Habib (2001) falsafat al-makan fi al-shi'r al-arabi. Damascus: Arab Writers Union, p.132

${ }^{x i}$ Abdarrahman, Issam (16/02/1990). Waqfah fi naharat Amman (وقة في نهارات عمان). Al-Dustur Newspaper

${ }^{x i i}$ Kahloush, Fathiyah (2008). Balaghatu-al-makan. Beirut: Dar al-intishar al-arabi, p. 243

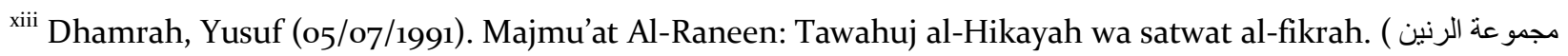
Al-Dustur

xiv Anani, Muhammad (1997). Al-Mustalahat al-Adabiyah al-Hadithah (الهصطلحات الأدبية الحديثة), Second edition. Cairo: International Egyptian Company for Publishing, p. 38

${ }^{x v}$ Saa'd, Majidah (2002). Al-bina' al-sardi fi qissass Emin Aoudah (البناء السردي في قصص أمين عودة). Afkar Magazine, issue 166, p. 70

القصة القصيرة/ النظرية ( (و التطبيق). Translated by Ali Ibrahim. Higher Council for Culture, p. 59

${ }^{\text {xvii }}$ Murashidah, Abdul-bassit (2009) sira' al-sulta wal-muthaqaf. Aadab Ain Shams Periodicals, vol. 37, p. 26

xviii Al-Shaykh, Khalil (20/08/1993). Tajribat Amin Oudah wa-al-bahth 'an al-huwiyah al-Qassassiyah ( تجربة) Al-Ra'y Newspaper

${ }^{\text {xix }}$ Al-ufuq Magazine (1992). first year, issue 24, Amman, p. 50

\section{Bibliography}

Abdarrahman, Issam (1990). Waqfah fi naharat Amman (وقفة في نهارات عمان). Al-Dustur Newspaper 
Al-Quralah, Zaid (02/o2//1993). Thabat al-qalaq fi majmu'at al-Raneen (ثبات القلق في مجمو عة الرنين). Al-Ra'y Newspaper

Al-Quralah, Zaid (13/11/1992). Al-sira' bayn al-dhat wal-akhar (الصراع بين الذات والآخر) Al-Ra'y Newspaper

Al-rimawi, Mahmoud (1995). Qissass Al-Raneen li Amin Oudah. (تصص الرنين لأمين عودة). Al-Ra'y Newspaper, Al-mulhaq al-thaqafi

Al-Shaykh, Khalil (1993). Tajribat Amin Oudah wa-al-bahth 'an al-huwiyah al-Qassassiyah (تجربة أمين عودة ، Al-Ra'y Newspaper

Al-ufuq Magazine (1992). Issue 24, Amman

Anani, Muhammad (1997). Al-Mustalahat al-Adabiyah al-Hadithah (الدصطلحات الأدبية الحديثة), Second edition. Cairo: International Egyptian Company for Publishing.

Oudah, Amin (1990). Tahawulat Mustapha Jabir (تحو لات مصطفى جابر) Irbid: Qudsiyah for Publishing and Distribution

Oudah, Amin (1991). Al-Raneen (الرنين) Irbid: Qudsiyah for Publishing and Distribution

Damrah, Yusuf (1991). Majmu’t Al-Raneen: Tawahuj al-Hikayah wa satwat al-fikrah. ( مجمو عة الرنين توهج الحكاية، Al-Dustur

Haddad, Nabil (2007). Al-ibda' wa-wihdat-al-intiba' (الإبداع ووحدة الانطباع). Amman: Jarir House for Publishing and Distribution

Imbert, Enrique, Anderson (200o) Al-qissah al-qassira: Annadhariyah wattatbiq (القصة القصيرة/ النظريةو النطبيق). Translated by Ali Ibrahim. Higher Council for Culture.

Ismael, Izz Al-din (2001) Al-ussus al-jamaliyah fi-al-naqd al-Arabi (الأسس الجمالية في النقد العربي). Beirut: Dar-alfikr al-Arabi

Jordanian Culture Ministry Website: http://www.culture.gov.jo/index.php?option=com_content\&view=article\&id=227\&Itemid=48\&lang=ar

Kahloush, Fathiyah (2008). Balaghatu-al-makan. Dar al-intishar al-arabi. Beirut

Khalil, Ibrahim et al (2009). Ma’alim al-hayat al-adabiyah fi Filastin wa-al-Urdun ( معالم الحياة الأدبية في فلسطين ووالأردن: Beirut: Al-mu'assasah al-arabiyah

Mu'nissi, Habib (2001) falsafat al-makan fi al-shi'r al-arabi. Arab Writers Union, Damascus

Murashidah, Abdul-bassit (2009) sira' al-sulta wal-muthaqaf. Adab Ain Shams Journal, vol. 37

Saa'd, Majidah (2002). Al-bina' al-sardi fi qissass Amin Oudah (البناء السردي في قصص أمين عودة). Afkar Magazine, 166. 